See discussions, stats, and author profiles for this publication at: https://www.researchgate.net/publication/280565341

\title{
Credit Channel and Capital Flows: A Macroprudential Policy Tool? - Evidence from Turkey
}

\section{Research · July 2015}

DOI: 10.13140/RG.2.1.1018.0962

\section{CITATIONS}

0

2 authors:

Serdar Varlik

Hitit University

11 PUBLICATIONS 1 CITATION

SEE PROFILE

\section{READS}

291

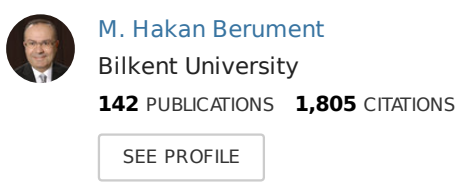

Some of the authors of this publication are also working on these related projects:

Energy Economics: Effect of Oil prices on macroeconomic variables View project

Economic Performance and Unemployment View project 


\title{
Credit Channel and Capital Flows: A Macroprudential Policy Tool? - Evidence from Turkey
}

\author{
Serdar Varlik \\ Department of Economics \\ Hitit University \\ 19000, Corum \\ Turkey \\ Phone: +90 5323409378 \\ Fax: +90 3122662529 \\ e-mail: varlikserdar@gmail.com \\ and \\ M. Hakan Berument" \\ Department of Economics \\ Bilkent University \\ 06800, Ankara \\ Turkey \\ Phone: +90 3122902342 \\ Fax: +90 3122662529 \\ e-mail: berument@bilkent.edu.tr
}

11 May 2014

* Corresponding Author. We would like to thank Rana Nelson for her valuable comments. 


\title{
Credit Channel and Capital Flows: A Macroprudential Policy Tool? - Evidence from Turkey
}

\begin{abstract}
The rapid credit growth induced by sudden capital inflows may negatively affect a country's economic performance, with the resulting outflows turning into a financial crisis. The purpose of this study is to determine whether the credit channel of monetary policy could be used as a macroprudential tool to suppress the effects of sudden capital inflows on economic performance for small open economies like Turkey. In this paper, using the VAR methodology employed by Bernanke, Gertler and Watson (1997), we investigate whether shutting down credit growth helps reduce the effects of capital inflows. Indeed, empirical evidence from Turkey shows that doing so decreases the effects of capital inflows on interest rate, industrial production and prices, but further appreciates the local currency. Therefore, we suggest that credit control might be partially used as a macroprudential policy tool.
\end{abstract}

JEL Codes: E51; E52; E58.

Key Words: Capital Flows; Credit Channel; Macroeconomic Prudential Policy. 


\section{Introduction}

Capital inflows as portfolio investments may affect a country's economic performance because of the external fragility of the domestic financial market, especially if achieved through the banking system. This effect on economic performance, frequently wrought through the credit channel, precipitates fluctuations in banks' balance sheets and may decrease credit quality. Moreover, currency appreciation may damage price stability and aggravate the current account deficit within the framework of financial stability. Since the 2008 global financial crisis, the magnitude of capital flows has become a factor in the financial stability of small open economies. Such countries, including Turkey, have begun to adopt various macroprudential policy tools to prevent the adverse effects of capital inflows; controlling bank credit growth is one such tool. This paper contributes to the literature on the subject by providing evidence for whether the credit channel can be used as a macroprudential tool to suppress the effects of sudden capital inflows on economic performance for small open economies like Turkey.

Sudden capital inflows may cause a surplus in credit supply, loosening credit standards and thus resulting in excessive credit growth (also called a credit boom). This situation can threaten price stability and financial stability by enlarging current account deficits, buoying asset prices and increasing domestic demand. Sudden capital inflows also increase the banking sector's foreign currency-denominated liabilities (Gourinchas et al., 2001; Elekdağ and Wu, 2011 and Magud et al., 2012). Adversely, a slowdown in short-term capital inflows, such as if the economy encounters the sudden stop problem, may damage economic performance through the credit channel and even result in a financial crisis (Calvo, 1998; Reinhart and Calvo, 2000). Barajas et al. (2009) call this scenario a bad credit boom, and it occurs because central banks (especially in developing countries) focus on the excessive credit growth induced by sudden capital inflows. Controlling credit growth through the credit channel may help reduce the domestic effects of sudden capital inflows.

The Turkish economy provides a convenient environment in which to study this possibility. Turkey achieved external financial liberalization in 1989, and since then, the relationship between sudden capital inflows and credit growth has been growing stronger, threatening financial stability. Başçı and Kara (2011) (governor and chief economist of the Central Bank of the Republic of Turkey (CBRT), respectively); Özatay (2011) (former CBRT deputy governor and former member of the CBRT's Monetary Policy Commission); Akkaya and Gürkaynak (2012) and Kara (2012) state that sudden capital inflows dramatically bring about two important results for Turkey: excessive credit growth and currency appreciation. The CBRT admits that these two factors as a result of capital inflows may result in price instability and financial instability. The CBRT (2012) and Alper et al. (2013) indicate that rapid currency appreciation induced by capital inflows may affect firms' willingness to borrow, leading to an excessive lending appetite in banks. Thus, the banking sector 
increases credits to the private sector excessively, which causes domestic demand to grow faster than aggregate income. This process is called a financial accelerator mechanism, and amplifies business cycles. Eventually, the current account deficit dramatically increases, in parallel with credit booms and currency appreciation, which results in macroeconomic instability and even financial crisis (Ganioğlu, 2012). An unforeseeable increase in credit growth and currency appreciation induced by intensive sudden capital inflows (also called hot money) negatively affect the current account balance. For example, in 2010, CBRT governor Yilmaz estimated that a five percent increase in credit growth would trigger a 2.1 percent increase in the current account deficit in Turkey for the year 2011 (Y1lmaz, 2010). Therefore, controlling excessive credit growth may contribute to a high current account deficit. Akçay and Ocakverdi (2012) suggest that controlling excessive credit growth may significantly reduce Turkey's high current account deficit. According to Kara et al. (2013), an average annual credit growth of 15 percent for Turkey would be reasonable in the medium term. In the summary of its Monetary Policy Committee Meeting of January 29, 2013, the CBRT stated that "[m]acroprudential measures will continue to be taken, should ...credit growth expectations exceed 15 percent for a long period."

There is substantial empirical research analyzing the validity of using the credit channel for monetary policy. ${ }^{1}$ The related literature is enlarged with the role of capital flow shocks on credits, especially for developing countries. These studies focus on the credit growth induced by capital inflows (see, for example, Gourinchas et al., 2001; Tornell and Westerman, 2002 and Duenwald et al., 2005). This literature has been growing rapidly since the global financial crisis: Mendoza and Terrones (2008), Bakker and Gulde (2010), Borio et al. (2011), Shin (2012), Cetorelli and Goldberg (2012) and Lane and McQuade (2013) all point out that capital flows and international liquidity determine fluctuations in credits (boom and busts) through the credit channel, and thus determine economic performance. All authors underline the adverse effects of credit growth induced by sudden capital inflows, and the Turkish case has plenty of evidence showing this relationship (see Alper and Sağlam, 2001; Aslan and Korap, 2007; Togan and Berument, 2011 and Binici and Köksal, 2012).

The purpose of this paper is to assess whether controlling the credits of the domestic banking system decreases the effects of sudden capital inflows on a small open economy. We investigate whether credit controls can be employed as an efficient macroprudential policy tool in Turkey. Hence, we analyze the impacts of capital flow shocks on the performance of the Turkish economy through the credit channel by using Bernanke, Gertler and Watson's (1997) vector autoregression (VAR) methodology. The empirical evidence gathered from the Turkish case suggests that shutting down the

\footnotetext{
${ }^{1}$ Such as Bernanke and Blinder (1992), Sims (1992), Gertler and Gilchrist (1994), Bernanke and Gertler (1995), Hubbard (1995), Cecchetti (1999), Kishan and Opiela (2000), Kashyap and Stein (2000), Ashcraft (2006), Fuinhas (2008) and Çevik and Teksöz (2012). In the Turkish case, Gündüz (2001), Şengönül and Thorbecke (2005), Arena et al. (2007), Brooks (2007), Demiralp (2008), Cambazoğlu and Güneş (2011) and Alper et al. (2012) argue that using the credit channel for monetary policy operates efficiently in Turkey, but Çavuşoğlu (2002), Çiçek (2005) and Aydın and Igan (2010) do not agree.
} 
credit channel decreases the effects of capital inflows on interest rate, industrial production and prices, but further appreciates local currency. Therefore, we suggest that credit controls might be partially used as macroprudential policy tool.

This paper is organized in five sections. In Section II, we briefly explain the relationship among capital flows, credits and the current account balance in Turkey. In Section III, we outline the methodology employed to assess the effect of shutting down the credit channel. Section IV presents the empirical evidence under alternative scenarios and Section $\mathrm{V}$ concludes the paper.

\section{The Relationship between Capital Flows and Credits in Turkey: A Short Story}

The banking sector plays an important role in the financial market, especially for developing countries such as Turkey. The relative importance of the banking sector for developing countries is due to its bigger share in the whole financial system, as it not only determines financial deepening and but also the efficiency of monetary policy (see Cecchetti, 1999). In the Turkish case, the banking sector's share of the balance sheet in the financial system was 91.5 percent in 2004 and 87.6 percent in 2012 (CBRT, 2005; 2013b). Although that share was lower in 2012, the banking sector remains highly dominant; while the percentage asset share of the banking sector in GDP was 71.2 percent in 2004, this ratio reached 98 percent in 2012 (Banking Regulation and Supervision Agency, 2006; 2012). Therefore, the credit channel, especially the bank lending channel, is important for the Turkish economy. After the introduction of structural reforms in 2001, the credit channel has been working more efficiently than other monetary policy transmission mechanisms (Başç1 et al., 2007).

To assess the importance of credit growth, we first provide a set of descriptive statistics (Table 1). The table shows a high correlation between credits and economic performance, which suggests the importance of the credit channel. The correlation coefficients between credits and consumer price index and between credits and industrial production are more than 0.85 . Furthermore, the correlation coefficient between credits and capital flows is 0.66 , which shows the close relationship between credits and capital flows.

Figure 1 shows the relationship between credits and capital flows, and between credits and the current account deficit. While real credit growth and capital and financial accounts move together, real credit growth and the current account deficit move in the opposite direction. To detect the fundamental relationship between credits and capital inflows, we focus on the years since external financial liberalization was achieved (1989 onward). Respectively, increases and decreases in real credit growth have been accompanied by capital inflows and outflows since the 1990s. As evident in Figure 1, during the 1994 financial crisis, while increase in real credit first slowed and then decreased, depending on capital outflow, the current account deficit also decreased and thus so did the current account surplus. Similarly, the 1998 Asian financial crisis induced capital outflows from Turkey because of decreased global risk appetite. These capital outflows led to decreases in real credit growth 
and current account deficits. This story among capital flows, credits and current accounts has often replayed itself in Turkey, especially since 1999. When the capital inflows in the pre-financial crisis period turned into capital outflows during the November 2000 and the February 2001 financial crises, real credit growth dramatically contracted, and correspondingly, a current account surplus emerged. In April 2001, the government announced the Transition to a Strong Economy Program, whose aims included banking sector soundness, price stability and lowered fiscal dominance; an (implicit) inflation targeting strategy began in January 2002. Also in 2002, the Banks' Association of Turkey and the Banking Regulation and Supervision Agency (BRSA) announced the Istanbul Approach, which engaged in a reconstruction of firms' credits. In 2005, Banking Law No. 5411 was enacted, covering prudential regulations for banks' credit standards. As a result of these measures, capital inflows to Turkey increased; correspondingly, real credit growth increased and, drastically, the current account deficit increased. Meanwhile, in December 2006 and February 2008, the BRSA increased general provisions for loans in order to control the credit risk carried by the banking sector's balance sheet.

When we analyze the period since the 2008 global financial crisis, we see that a decrease in global risk appetite and an increase in Turkey's risk premium primarily slowed capital inflows to Turkey, but then initiated capital outflows. Throughout 2009, real credit growth rapidly decreased, which caused a decrease in the current account deficit. Nevertheless, the monetary policy implemented by the CBRT (such as reducing the policy rate and the reserve requirement ratio after 2008), and capital inflows as a result of soaring global liquidity, induced especially by the US Federal Reserve's Quantitative Easing-II policy, reinitiated an increase in real credit growth as of the beginning of 2010. Thereupon, within the framework of its Monetary Policy Exit Strategy, implemented in April 2010, the CBRT began to increase reserve requirement ratios to prevent rapid credit growth. Again, the CBRT determines the different reserve requirement ratios for domestic- and foreign-currencydenominated deposits. In this way, it aims to increase the efficiency of the reserve requirement ratio ${ }^{2}$ (Başçı and Kara, 2011; Kara, 2012). The CBRT also terminated interest payments for reserve requirements denominated by domestic currency in September 2010. Then, in December 2010, the CBRT differentiated reserve requirement ratios for deposits at different maturities, and expanded the scope of reserve requirements. However, this increase in reserve requirement ratios did not curb credit growth until the last quarter of 2011; conversely, credit growth drastically increased and the current account deficit increased as well. ${ }^{3}$ The rapid credit growth was only stemmed after the BRSA

\footnotetext{
${ }^{2}$ On the other hand, the CBRT has been altering the framework of its monetary policy since the last quarter of 2010 by using new monetary policy tools such as an asymmetric interest rate corridor and the Reserve Option Mechanism (ROM) to prevent the domestic effects of external fragility such as excessive credit growth and currency appreciation induced by sudden capital inflows (CBRT, 2011; Akçelik et al., 2013). This new approach involved a paradigm shift in monetary policy practice for Turkey (Üçer, 2011).

3 Özatay (2011), former CBRT deputy governor and former member of the CBRT Monetary Policy Commission, ascribes the failure of the reserve requirement policy to control credit growth to the banking
} 
implemented a microprudential policy to support the CBRT's macroprudential policy. To that end, the BRSA increased the rate of its Resource Utilization Support Fund and Loan to Value taxes, which contributed to slowing credit growth after the third quarter of 2011 (CBRT, 2012b). As a result of the ongoing slowdown in the global economy, the policies implemented by the CBRT, as well as the measures taken by the BRSA, credit growth came down to "reasonable levels" by the end of 2012 (CBRT, 2012b, p. 35). Furthermore, the CBRT (2012a) determined the targets for an average annual rate of increase in credit growth to be 15 percent, which resembles the credit rule for monetary policy in 2013. Thus, on the one hand, the CBRT began to use an asymmetric interest rate corridor system to discourage capital inflows and to prevent an annual credit growth of more than 15 percent, and on the other hand, implemented the ROM and reserve requirements, respectively, to provide currency and credit growth stability. Controlling credit growth thus plays a large part in the CBRT's new monetary policy framework in terms of price stability and financial stability.

\section{Methodology}

In this section, we first introduce the benchmark VAR specification that we use to assess the effect of capital flows on economic performance. Later, we outline how the effects of capital flow on economic performance are gathered through different credit channel working conditions.

The benchmark VAR specification is the regular VAR specification, which includes variable as a measure of capital flow, exchange rate, interest rate, credits, industrial production and the consumer price index. We use a lag order of six, according to the Final Error Prediction Criteria. We repeat the same exercise with two lags, as suggested by the Bayesian Information Criteria. The results, reported later in the paper, are robust. We include 11 monthly dummies to account for seasonality. Moreover, to account for financial crisis periods, we include intercept dummies for the each period from the second to the fifth months of 1994, the eleventh month of 2000 and the second month of 2001.

To identify capital flow shocks, we employ the Cholesky decomposition; thus, the order of variables is important. All variable placements are affected by preceding variables contemporaneously but are not affected by latter variables contemporaneously. However, all the variables affect each other with a lag. The variables are ordered as capital flow measure, exchange rate, interest rate, credits, industrial production and consumer price index. Thus, capital flow measures affect capital flow measures, exchange rate, interest rate, credits, industrial production and consumer price index

system's close substitution relationships regarding liabilities maturities. Akkaya and Gürkaynak (2012) agree; their study suggests that the reserve requirement policy failed because when the CBRT increased reserve requirement ratios, banks steered towards nondeposit funds such as foreign swaps to finance credits. Therefore, not only the change of deposit to total asset ratio increased, but so did the credits to total asset ratio. Üçer (2011) and Özatay (2012) maintain that as the CBRT increased reserve requirement ratios, banks compensated by diminishing liquidity by again borrowing from the CBRT's open market operations. In that case then, reserve requirements were not efficient tools for reducing credits. 
contemporaneously but are not affected by these variables contemporaneously. Similarly, exchange rate is affected by capital flow contemporaneously and affects subsequent variables contemporaneously. However, again, all of these variables affect each other with a lag.

To assess the effects of capital flows on economic performance under the different credit variable scenarios, we employ the methodology Bernanke, Gertler and Watson (1997) adopted. Thus, we use three VAR scenarios to attain direct and indirect results of capital flow shocks. The first scenario is the conventional impulse simulation that uses the unrestricted VAR, which we call the base scenario, and it shows the impulse responses of the variables to a one standard deviation in capital and financial accounts. The next two VAR simulations involve alternative methods of shutting down credit response. In the second scenario, we shut down the credits such that credit level stays at the pre-shock period and does not respond to any other variable. In the third scenario, credits respond to all other variables but not to capital flow shocks, so capital flow shocks affect the credit variable indirectly. In the figures presenting the impulse responses, we indicate the base, second and third scenarios, respectively, as a solid line, dotted line and dashed line.

\section{Empirical Results}

We used monthly data for the period between January 1992 and May 2013. Although CBRT announced that they try to limit credit growth to control capital flows after 2010, it is common for Turkish policy makers to intervene in banks' credit limits, as evident by statements made by the prime minister just after the 2008 financial crisis began, and by the abovementioned Istanbul Approach. Thus, our sample starts in January 1992 with the onset of the monthly availability of data on current account balances.

As an economic performance indicator, overnight interbank interest rate is used for interest rate, consumer price index is used for prices and industrial production is used for income. Total credits to private sector are used for credits that consist of credits extended by conventional commercial, investment, development and participation banks. Another economic performance indicator is exchange rate. We use two different exchange rates: (i) The Turkish lira value of the US dollar and (ii) the Turkish lira value of the basket of 1 US dollar +1 Euro. ${ }^{4}$ Furthermore, we choose two variables for the capital flow measures: hot money, as employed by Loungani and Mauro (2000), ${ }^{5}$ and current account balance. Even if the latter variable is not direct measure capital flow, it is a variable that

\footnotetext{
${ }^{4}$ The Euro series was not available before January 1999, thus we used the fixed exchange rate between the Euro and the Deutsche Mark to calculate the Euro exchange rate.

${ }^{5}$ Loungani and Mauro (2000) define three hot money measures based on balance of payment: Hot Money I consists of the sum of Net Error and Omissions, Other Investment (Assets) and Other Investment (Liabilities) held by entities other than the monetary authorities, general government and banks. Hot Money II equals Hot Money I plus Other Investment (Assets) and Other Investment (Liabilities) held by banks. Broad Hot Money includes Hot Money II plus Net Flows of Portfolio Investment Assets and Liabilities in the form of Debt Securities.
} 
policy makers are concern as a stability measure. Those two variables are deflated with the lag value of the interpolated monthly GDP to normalize before using them in the analyses. We use the lag value of GDP to avoid simultaneity, that is, so that other variables do not affect the current account balance through GDP. All these variables enter the system in logarithms except interbank interest rate and capital flow measures. All data used in this study are gathered from the CBRT's Electronic Data Delivery System (EDDS).

Figure 2 reports the impulse response functions for three types of specifications when a onestandard-deviation shock is given to capital and financial account balances, and reports how this shock affects economic performance. Impulse response functions shown with solid lines are for the conventional VAR specification (base scenario). Impulse response functions shown with dotted lines are for the impulse response that credit level does not change; it does not respond to any variable (second scenario). The third type of impulse response function is shown with a dashed line, and is gathered when credits respond to all other variables (except capital flow shock), such as exchange rate, interbank rate, industrial production and consumer price index.

Figure 2.1 reports how a one-standard-deviation shock to capital flow affects itself for 18 periods. The three impulse responses more or less coincide and the effect dies out more or less after the third period. Figure 2.2 reports the impulse responses on how the exchange rate responds. The nominal exchange rate decreases (local currency appreciates) in the first month. Although the exchange rate increases and exceeds its initial level, after the fourth period appreciation prevails for all three specifications. Currency appreciates most when credits are kept constant. The solid lines and the dashed lines (the first and the third scenarios, respectively) are similar, but currency appreciation when credits do not respond to capital flow occurs more than in the other two scenarios. This response makes sense because credits increase import demand mostly for investment goods and raw materials, and put pressure on the exchange rate to depreciate. Thus, appreciation should be higher under a zero credit growth constraint. It is also possible that export decreases with credit growth constraints. However, the empicial evidence suggests that import responds more than export to capital flow, the credit growth for first three periods not statistically significant after the forth period when a onestandard-deviation shock is given to credits. Thus, this also supports the higher appreciation under a zero credit growth constraint. ${ }^{6}$

Figure 2.3 reports the impulse responses for the interbank interest rate. Interest rate decreases and remains below the pre-shock level in all three scenarios for five periods. For the base scenario and the third scenario (when only credit does not respond to capital flows), interest rate briefly exceeds the pre-shock level. However, when credits are kept constant, interest rate remains below the pre-shock level. In the second scenario overall, interest rate decreases the most.

\footnotetext{
${ }^{6}$ We did not report those impulse responses for 'import' and "import-export ratio", but they are available from the authors upon request.
} 
Figure 2.4 reports the impulse responses to credits (except for the impulse responses in no credit growth). In the other two scenarios, credits increase with capital flows. Furthermore, increase in credit is greatest in the base scenario.

Figure 2.5 reports the impulse responses of industrial production, which increased in all three scenarios but not as much in the first nine periods, when credit growth was zero. In other words, credits to private sector, which increase quickly in the first nine months, induce an increase in industrial production in the first and the third scenarios, but less of an increase in the second scenario, when credit growth is zero. Again, the impulse responses when credit growth is not constrained and constrained not to respond to capital flows are similar.

Figure 2.6 reports the impulse responses for consumer price index. Capital flows decrease the prices in all three scenarios for the first five periods. In parallel with currency appreciation, consumer price index decreases and then begins to increase under the first and the third scenarios. However, prices always remain lower than in the pre-shock period, when credit growth was zero. Therefore, the decrease in consumer price index is highest when credit growth is constrained to zero.

Once we compare the impulse responses that respond to all the variables (except capital flows) to the impulse responses with no credit constraint, the difference is nil.

Almost all series in the VAR specification are persistent. Thus, they may also move together. However, the source of the movement might be the time trend. Figures 3.1 to 3.6 report the corresponding impulse responses in which the VAR model includes the time trend from the previous specification. The results are robust.

The lag order selection was kept at six with the Final Error Prediction Criteria. However, the model could be overparameterized and thus the estimates may not be efficient. The Bayesian Information Criteria suggests that an optimal lag order of two. Thus, Figures 4.1 to 4.6 report the corresponding impulse responses with a VAR model of two lags. The results are robust.

The CBRT stated that it is not only the level of the current account deficit, but also financing that is a problem. The CBRT is also concerned about hot money; Figures 5.1 to 5.6 report the impulse responses by replacing current account deficit with hot money (as defined by Loungani and Mauro (2000)). The estimation is robust with our benchmark analyses in Figures 2.1 to 2.6.

Turkey is a small open economy, with its exports/revenues mostly denominated in Euros and its imports/payments mostly denominated in US dollars (see Berument and Dinçer, 2007). Thus, in our calculations, it is the Euro exchange rate that also matters. Figures 6.1 to 6.6 report the impulse response with the basket of 1 USD +1 Euro as the exchange rate. Again, the results are parallel to the benchmark specification.

Togan and Berument (2011) argue that credits do not affect the economic performance but that they respond to economic performance. To account for this situation, we place credits last in the ordering. Figures 7.1 to 7.6 report these responses, and they are parallel to Figures 2.1 to 2.6. Overall, we suggest that the basic conclusion of our specification is robust. 


\section{Conclusion}

This paper assesses the role of credit growth in controlling the adverse effects of capital flows on economic performance. To address these effects, we use Bernanke, Gertler and Watson's (1997) methodology, which imposes certain credit growth scenarios on impulse response functions gathered from a base-line VAR model.

In this paper, we gather three different impulse responses from different credit growth scenarios when a one-standard-deviation shock is given to capital flows. In the first scenario (the base scenario) we did not impose any constraints on credit growth, and thus conventional impulse responses were gathered from the VAR specification. In the second scenario, we shut down the credit channel; that is, the credit level was equal to its pre-shock level and stayed there. In the third scenario, credits responded to all the variables except capital flow measures.

In all these scenarios, as expected, capital flows appreciated the local currency, decreased the interest rate and prices and increased credits and output. When the credit growth was constrained to zero, the effect of capital flows on economic performance was decreased, but local currency appreciation increased. In that sense, constraining credits delivers all the desired properties but undesirably appreciates local currency. Once we compared the impulse responses regarding how credits responded to all the variables (except capital flows) with the base-line scenario, the effect of credit control was minimal. For the above reasons, we suggest that the credit channel can be used as monetary policy tool only in certain instances. 


\section{References}

Akçay, C., \& Ocakverdi, Eren. (2012). An Interim Assessment of the Ongoing Turkish Monetary and Macro Prudential Experiment, İktisat İsletme ve Finans, 27(315), 77-92.

Akçelik, Y., Başç1, E., Ermişoğlu, E., \& Oduncu, Arif. (2013). The Turkish Approach to Capital Flow Volatility, CBRT Working Paper, 13(06).

Akkaya, Y., \& Gürkaynak, S. R. (2012). Current Account Deficit, Budget Balance, Financial Stability and Monetary Policy: Reflections on a Gripping Episode, İktisat Issletme ve Finans, 27(315), 93-119.

Alper, C. E., \& Sağlam, I. (2001). The Transmission of a Sudden Capital Outflow: Evidence from Turkey, Eastern European Economics, 39(2), 29-48.

Alper, K., Hülagu, T., \& Kele, G. (2012). An Empirical Study on Liquidity and Bank Lending, CBRT Working Paper, 12(04).

Alper, K., Kara H., \& Yörükoğlu, M. (2013). Alternative Tools to Manage Capital Flow Volatility, CBRT Working Paper, 13(31).

Ashcraft, B. A. (2006). New Evidence on the Lending Channel, Journal of Money, Credit and Banking, 38(3), 751-775.

Aslan, Ö. \& Korap, H. L. (2007). Monetary Transmission Mechanism in An Open Economy Framework: The Case of Turkey, Ekonometri ve İstatistik, 5, 41-66.

Arena, M., Carmen, M., R. \& Vasquez, F. F. (2007), The Lending Channel inEmerging Economies: Are Foreign Banks Different?, IMF Working Paper, 07(48).

Aydin, B., \& Igan, D. (2010). Bank Lending in Turkey: Effects of Monetary and Fiscal Policies", IMF Working Paper, 10(233).

Bakker, B. B., \& Gulde, A. M. (2010), The Credit Boom in the EU New Member States: Bad Luck or Bad Policies?, IMF Working Paper, 10(130).

Issue. 1-2.

Banking Regulation and Supervision Agency, (2006). Financial markets Report, March-June, Issue. 28

Banking Regulation and Supervision Agency, (2012). Financial markets Report, December,

Barajas, A., Dell'Ariccia, G., \& Levchenko, A. (2009). Credit Booms: the Good, the Bad, and the Ugly, http://www.nbp.gov.pl/Konferencje/NBP Nov2007/Speakers/Dell Ariccia.pdf.2013.12.11.

Başçı, E., Özel, Ö., \& Sarıkaya, Ç. (2007). The Monetary Transmission Mechanism in Turkey:

New Developments, CBRT Working Paper, 07(04).

Başç1, E., \& Kara, A. H. (2011). Financial Stability and Monetary Policy, İktisat Issletme ve Finans, 26(302), 9-25.

Bernanke, S. B., \& Blinder, S. A. (1992). The Federal Funds Rate and the Channels of Monetary Transmission, American Economic Review, 82(4), 901-921.

Bernanke, S. B., Gertler, M., \& Watson, M. (1997). Systematic Monetary Policy and the Effects of Oil Price Shocks, Brookings Papers on Economic Activity, 1, 91-157.

Berument, M. H., \& Dinçer, N. (2007). The Effects of Exchange rate Risk on Economic

Performance: The Turkish Experience, Applied Economics, 36(21), 2429-2441.

Binici, M., \& Köksal, B. (2012), Determinants of Credit Booms in Turkey, MPRA Paper, 38032

Borio, C., McCauley, R., \& McGuire, P. (2011), Global Credit and Domestic Credit Booms, BIS Quarterly Review, September, 43-57.

Brooks, P. K. (2007). The Bank Lending Channel of Monetary Transmission: Does itWork in Turkey?, IMF Working Paper, 07(272).

Calvo, A. G. (1998). Capital Flows and Capital-Market Crises: The Simple Economics of Sudden Stops, Journal of Applied Economics, 1(1), 35-54.

Cambazoğlu, B., \& Güneş, S. (2011). Monetary Transmission Mechanism in Turkey and Argentina, International Journal of Economics and Finance Studies, 3(2), 23-33

Cecchetti, G. S. (1999). Legal Structure, Financial Structure, and Monetary Policy

Transmission Mechanism, FRBNY Economic Policy Review, 5(2), 9-28.

Central Bank of the Republic of Turkey, (2005). Financial Stability Report, August, 1. 
Central Bank of the Republic of Turkey, (2010). Monetary and Exchanege Rate Policy for 2011.

Central Bank of the Republic of Turkey, (2011). Monetary and Exchanege Rate Policy for 2012.

Central Bank of the Republic of Turkey, (2012a). Monetary and Exchanege Rate Policy for 2013.

Central Bank of the Republic of Turkey, (2012b). Financial Stability Report, 15, November.

Central Bank of the Republic of Turkey, (2013). Financial Stability Report, 16, May.

Cetorelli, N., \& Goldberg, L. (2012), Banking Globalization and Monetary Transmission, Journal of Finance, 67(5), 1811-1843.

Çavuşoğlu, T. (2002). Credit Transmission Mechanism in Turkey: An Emprical Investigation,

Middle East Technical University ERC Working Papersin Economics, 02(03), 1-30.

Çevik, S., \& Teksöz, K. (2012). Lost in Transmission? The Effectiveness of Monetary Policy

Transmission Channels in The GCC Countries, IMF Working Paper, 12(191).

Çiçek, M. (2005). The Monetary Transmission Mechanism in Turkey: An Analysis through VAR (Vector Autoregression) Approach, Iktisat Issletme ve Finans Dergisi, 20(233), 82-105.

Demiralp, S. (2008). Money and the Monetary Transmission Mechanism in Turkey, Iktisat İsletme ve Finans Dergisi, 23(264), 5-20.

Duenwald, K. C., Gueorguiev, N., \& Schaechter, A. (2005), Too Much of a Good Thing? Credit Booms in Transition Economies: The Cases of Bulgaria, Romania, and Ukraine, IMF Working Paper, 05(128).

Elekdağ, S., \& Wu, Y. (2011). Rapid Credit Growth: Boon or Boom-Bust?, IMFWorking Paper, 11(241).

Fuinhas, J. A. (2008). Monetary Transmission and Bank Lending in Portugal: A Sectoral Approach, The IUP Journal of Monetary Economics, 6(1), 34-60.

Ganioğlu, A. (2012). Finansal Krizlerin Belirleyicileri Olarak Hızlı Kredi Genişlemeleri ve Cari İşlemeler Açı̆̆

Gertler, M., \& Gilchrist, S. (1994). Monetary Policy, Business Cycles, and the Behaviour of Small Manufacturing Firms, The Quarterly Journal of Economics, 109(2), 309-340.

Gourinchas, P. O., Valdes, O. R., \& Landerretche, O. (2001). LendingBooms: Latin America and the World, NBER Working Paper Series, 8249.

Gündüz, L. (2001). Monetary Transmission Mechanism in Turkey and Bank Lending Channel, IMKB Journal, 18(5), 13-30.

Hubbard, R. G. (1994). Is There a Credit Channel for Monetary Policy?, NBER Working Paper, 4977.

Kara, A. H. (2012). Monetary Policy in the Post-Crises Period, Iktisat Isşletme ve Finans, 27(315), 9-36.

Kara, A. H., Küçük, H., Tiryaki, S. T., \& Yüksel, C. (2013). In Search of a Reasonable Credit Growth Rate for Turkey?, CBRT Research Notes in Economics, January, 2013-03.

Kashyap, K. A., \& Stein, C. J. (2000). What Do a Million Observations on Banks Say about the Transmission of Monetary Policy?, American Economic Review, 90(3), 407-428.

Kishan, R., \& Opiela, T. (2000), Bank Size, Bank Capital, and the Bank Lending Channel, Journal of Money, Credit, and Banking, 32(1), 121-41.

Lane, R. P., \& McQuade, P. (2013). Domestic Credit Growth and International Capital Flows, European Central Bank Working Paper Series, July, 1566.

June, 6 .

Loungani, P., \& Mauro, P. (2000). Capital Flight From Russia, IMF Policy Discussion Paper,

Magud, E. N., Reinhart, M. C., \& Vesperoni, R. E. (2012). Capital Inflows, Exchange Rate Flexibility, and Credit Booms, IMF Working Paper, 12(41).

Mendoza, G. E., \& Terrones, E. M. (2008). An Anatomy of Credit Booms: Evidence from Macro Aggregates and Micro Data, NBER Working Paper Series, 14049.

Mishkin, S. F. (1996). The Channels of Monetary Policy Transmission: Lessons for Monetary Policy, NBER Working Paper Series, 5464.

Özatay, F. (2011). The New Monetary Policy of the Central Bank: Two Targets-Three Intermediate Targets-Three Tools, Iktisat Işsletme ve Finans, 26(302), 27-43. 
Özatay, F. (2012). An Exploration into New Monetary Policy, İktisat Işsletme ve Finans, 27(315), 51-75.

Reinhart, M. C., \& Calvo, A. G. (2000). When Capital Inflows Come to A Sudden Stop: Consequences and Policy Options. P. Kenen \& A. Swoboda (Ed). Reforming the International Monetary and Financial System, (pp. 175-201), Washington DC: International Monetary Fund.

Şengönül, A., \& Thorbecke, W. (2005). The Effect of Monetary Policy on Bank Lending in Turkey, Applied Financial Economics, 15(13), 931-934. 155-192.

Shin, H. S. (2012), Global Banking Glut and Loan Risk Premium, IMF Economic Review, 60,

Sims, A. C. (1992). "Interpreting the Macroeconomic Time Series Facts", European Economic Review, 36(5), 975- 1011.

Togan, S., \& Berument M.H. (2011), Current Account Balance, Capital Flows and Credits, Bankacılar Dergisi, 78, 3-21.

Tornell, A., \& Westermann, F. (2002), Boom-Bust Cycles in Middle-Income Countries: Facts and Explanation, IMF Staff Papers, 49, 111-55.

Üçer, M. (2011). Observation on Recent Monetary Policy Measures, Iktisat Işsletme ve Finans, 26(302), 45-51.

Y1lmaz, D. (2010). Guvernor Y1lmaz's Presentation at the Meeting with the General Menagers of the Banks, 23.12.2010, Ankara. 
Table 1: Correlation Coefficents between Nominal and Real Credits and Other Variables

\begin{tabular}{lccccccc}
\hline & $\begin{array}{c}\text { Capital and } \\
\text { Financial } \\
\text { Account }\end{array}$ & $\begin{array}{c}\text { Hot } \\
\text { Money }\end{array}$ & $\begin{array}{c}\text { Nominal } \\
\text { Exchange } \\
\text { Rate }\end{array}$ & $\begin{array}{c}\text { Interbank } \\
\text { Rate }\end{array}$ & $\begin{array}{c}\text { Industrial } \\
\text { Production }\end{array}$ & $\begin{array}{c}\text { Consumer } \\
\text { Price Index }\end{array}$ & $\begin{array}{c}\text { Current } \\
\text { Account } \\
\text { Balance }\end{array}$ \\
\hline Nominal Credit & 0.66 & 0.54 & 0.71 & -0.51 & 0.85 & 0.88 & -0.80 \\
Real Credit & 0.66 & 0.52 & 0.70 & -0.50 & 0.87 & 0.87 & -0.82 \\
\hline
\end{tabular}

Source: CBRT

Figure-1: The Relationship between Real Credit Growth and Balance of Payment

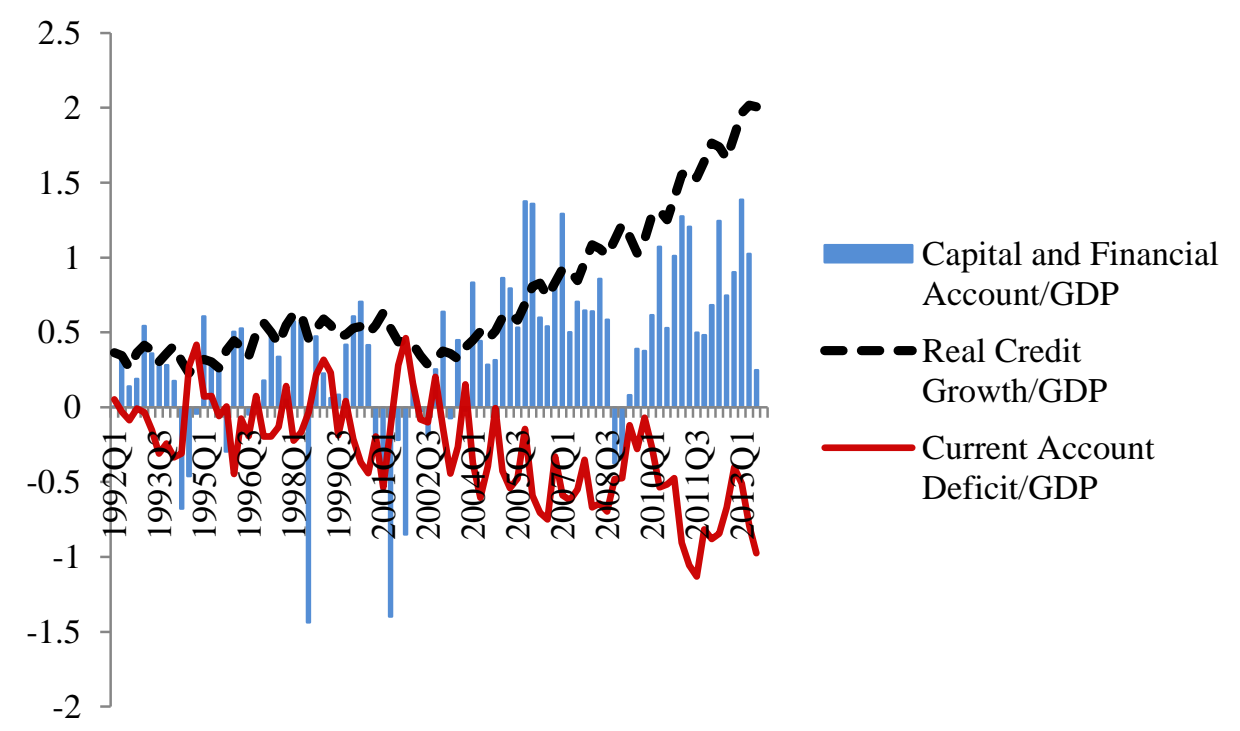

Source: CBRT 


\section{Figure 2: Responses to Capital Flows}
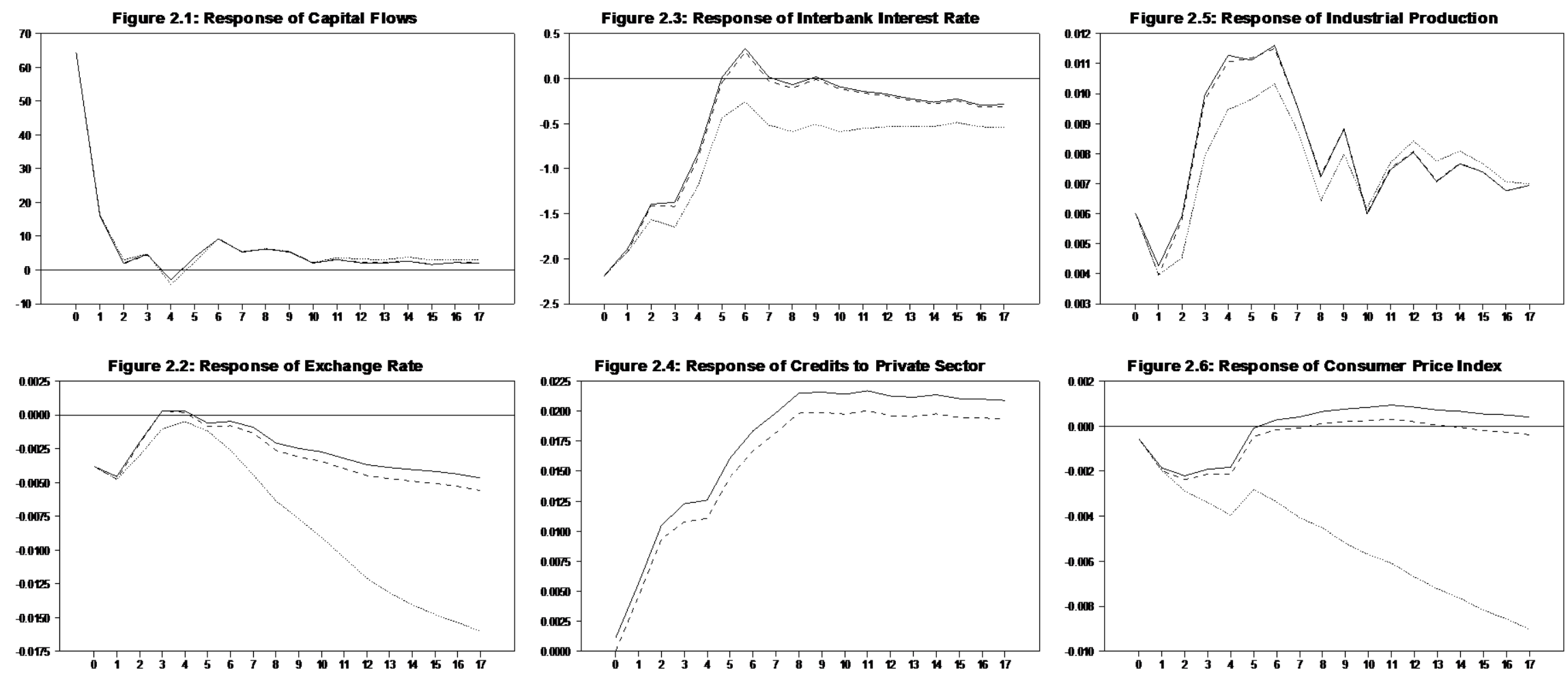

Note: The solid line represents the impulse response of the unconstrained specification. The dotted line represents the impulse response when credit is kept constant. The dashed line represents the impulse response for when credit does not change with capital flows but changes with other variables. 


\section{Figure 3: Responses to Capital Flows with the Time Trend}
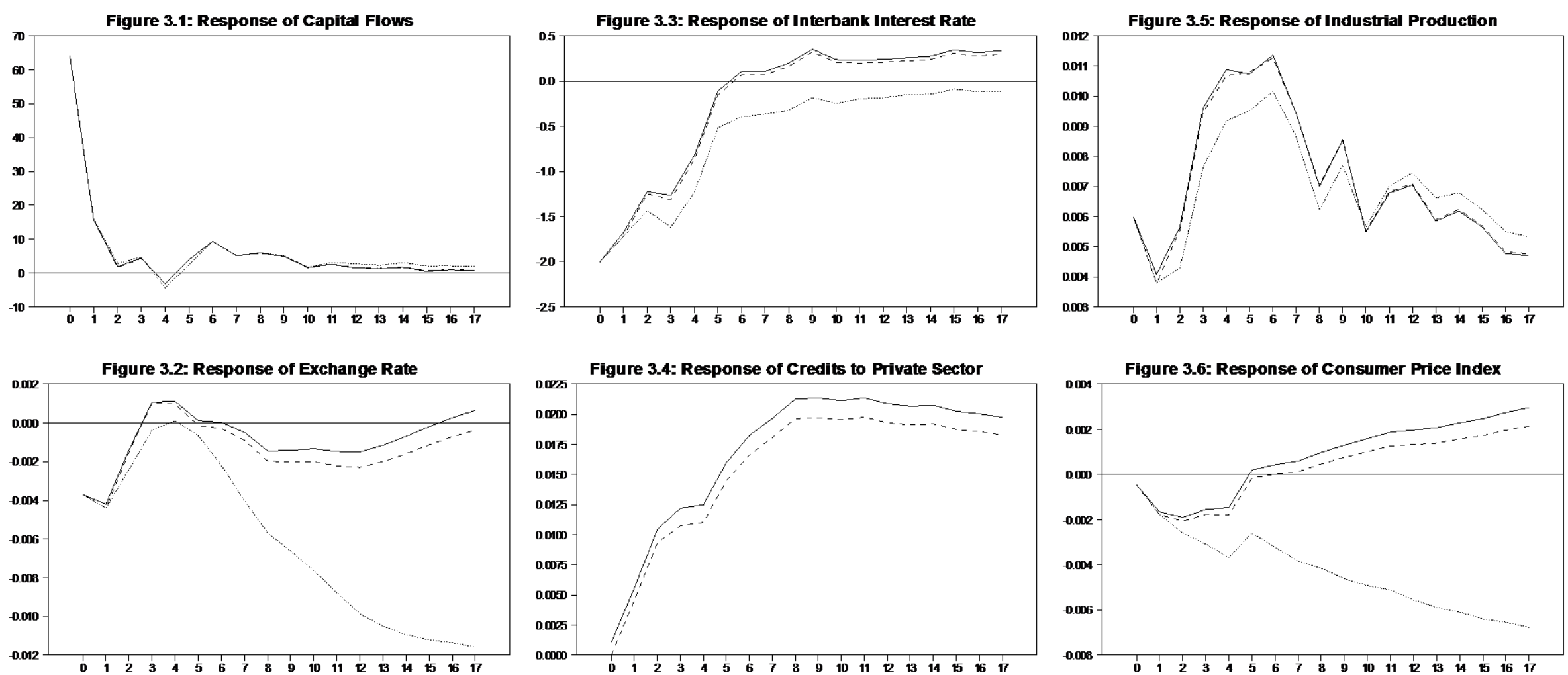

Note: The solid line represents the impulse response of the unconstrained specification. The dotted line represents the impulse response when credit is kept constant. The dashed line represents the impulse response for when credit does not change with capital flows but changes with other variables. 


\section{Figure 4: Responses to Capital Flows with Two-lags}
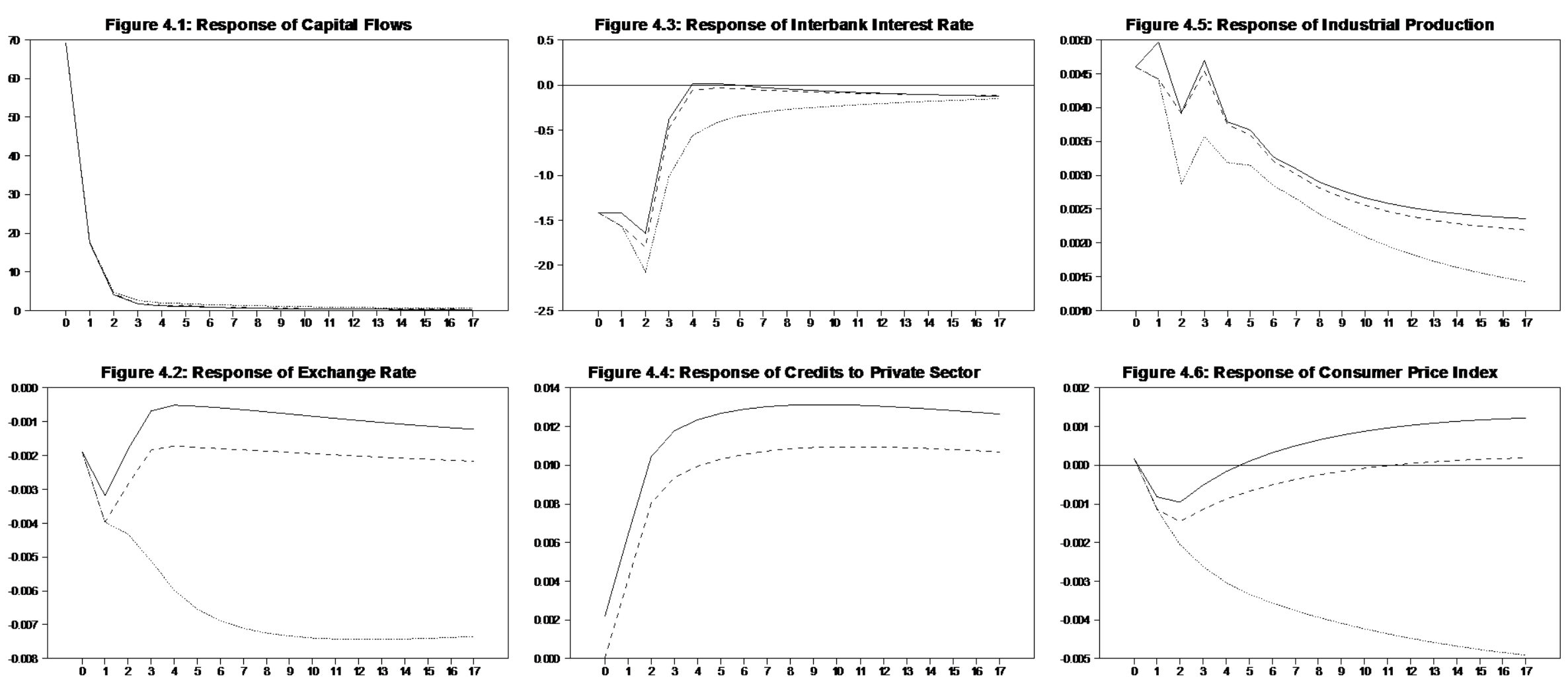

Note: The solid line represents the impulse response of the unconstrained specification. The dotted line represents the impulse response when credit is kept constant. The dashed line represents the impulse response for when credit does not change with capital flows but changes with other variables. 


\section{Figure 5: Responses to Hot Money}
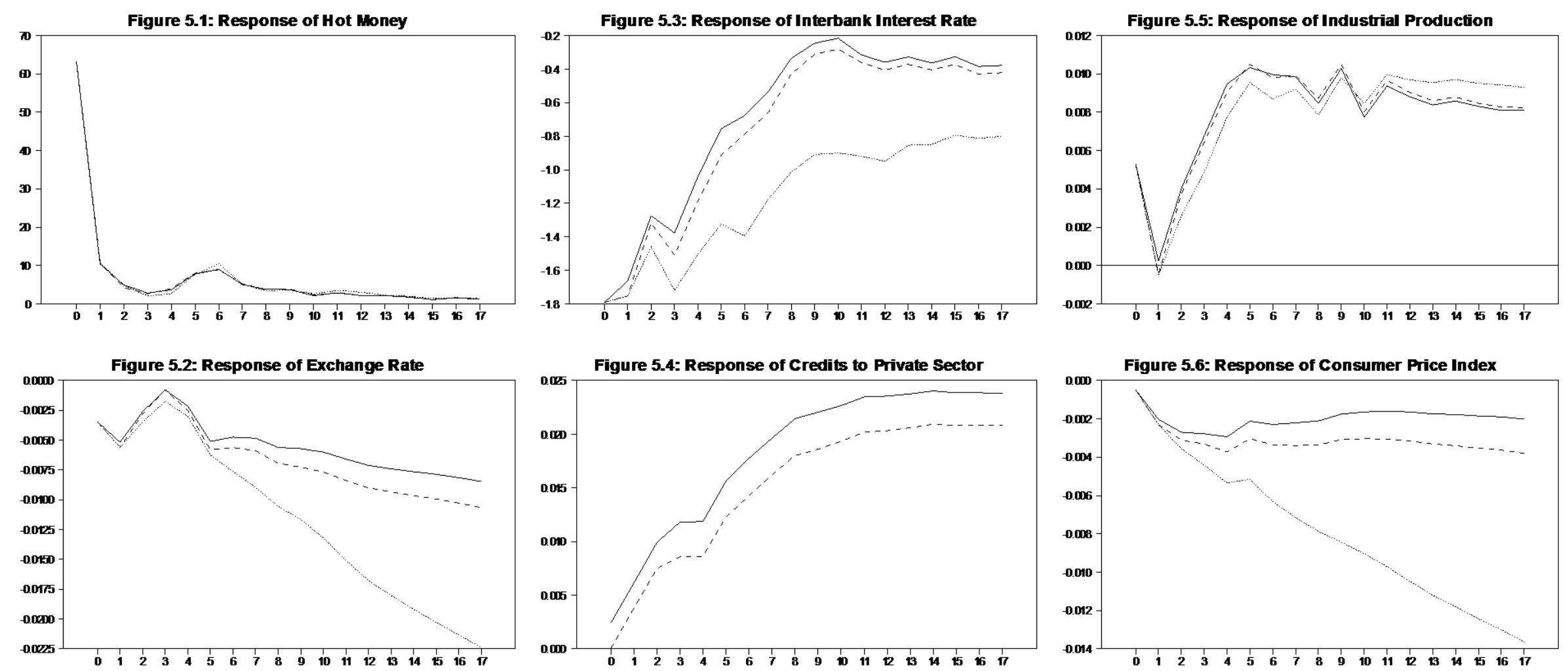

Note: The solid line represents the impulse response of the unconstrained specification. The dotted line represents the impulse response when credit is kept constant. The dashed line represents the impulse response for when credit does not change with capital flows but changes with other variables. 
Figure 6: Responses to Capital Flows with The Exchange Rate Basket
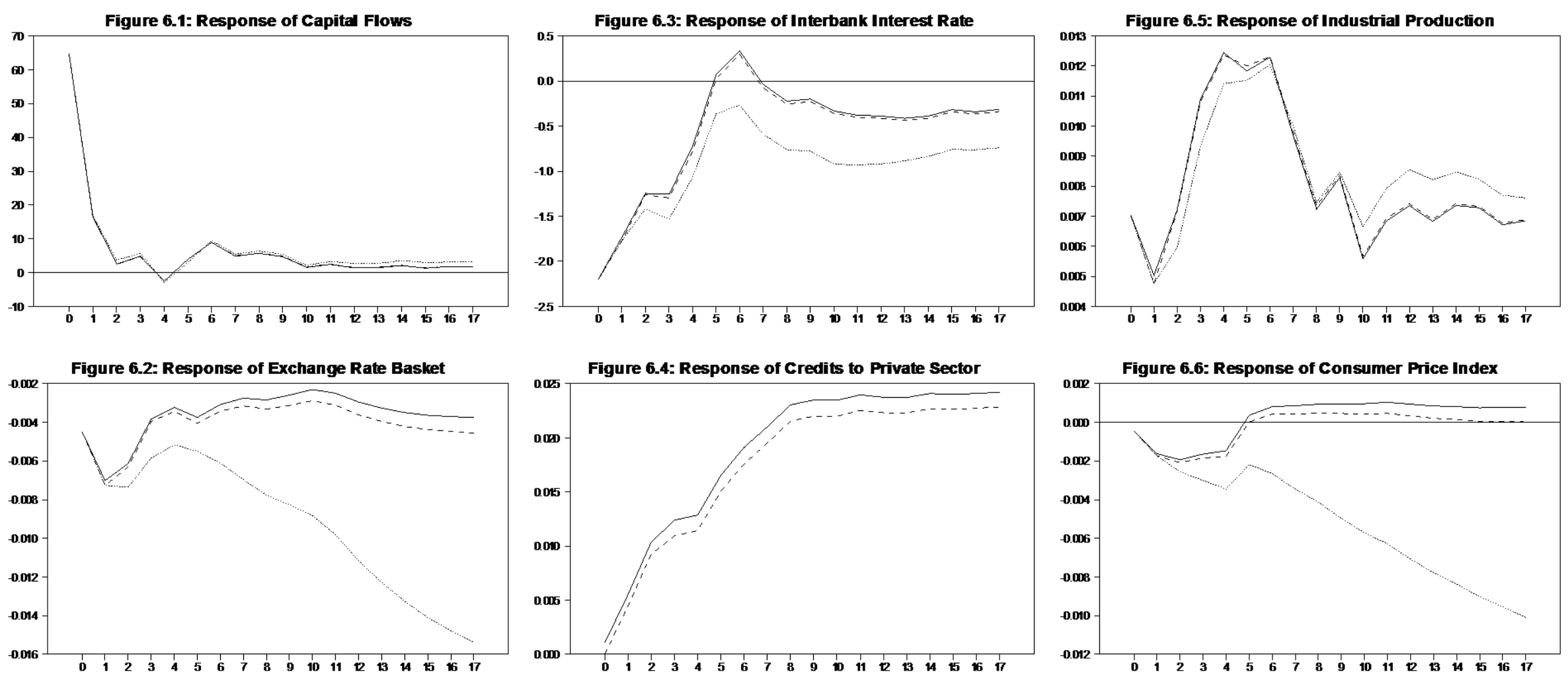

Note: The solid line represents the impulse response of the unconstrained specification. The dotted line represents the impulse response when credit is kept constant. The dashed line represents the impulse response for when credit does not change with capital flows but changes with other variables. 


\section{Figure 7: Shock to Capital Flows with Recordered Variable: Credit Ordered Last}
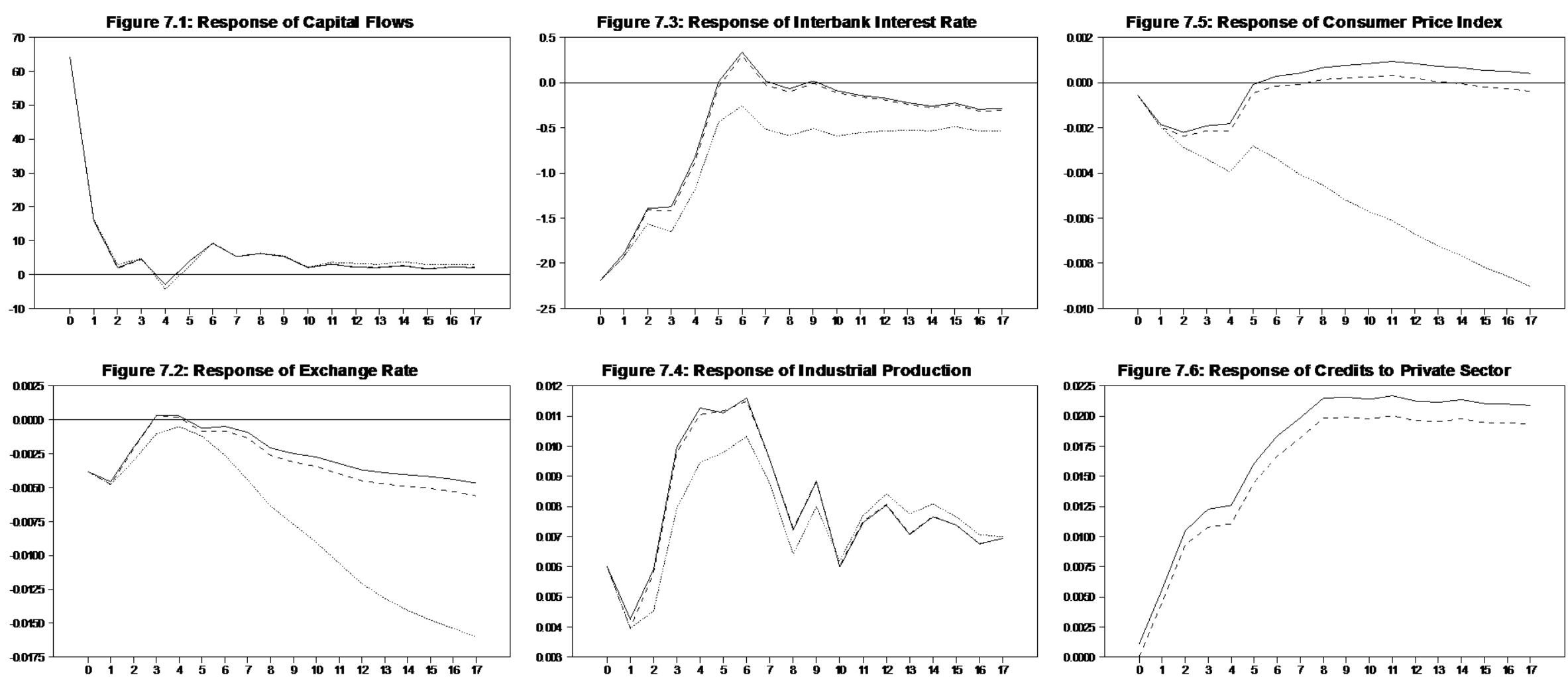

Note: The solid line represents the impulse response of the unconstrained specification. The dotted line represents the impulse response when credit is kept constant. The dashed line represents the impulse response for when credit does not change with capital flows but changes with other variables. 
Credit Channel and Capital Flows: A Macroprudential Policy Tool? - Evidence from Turkey

---NOT FOR PUBLICATION--- 
The following is the base model, where Import-GDP ratio is used as the additional variable. Imports are negative.

\section{S1: Responses to Capital Flows with Import}
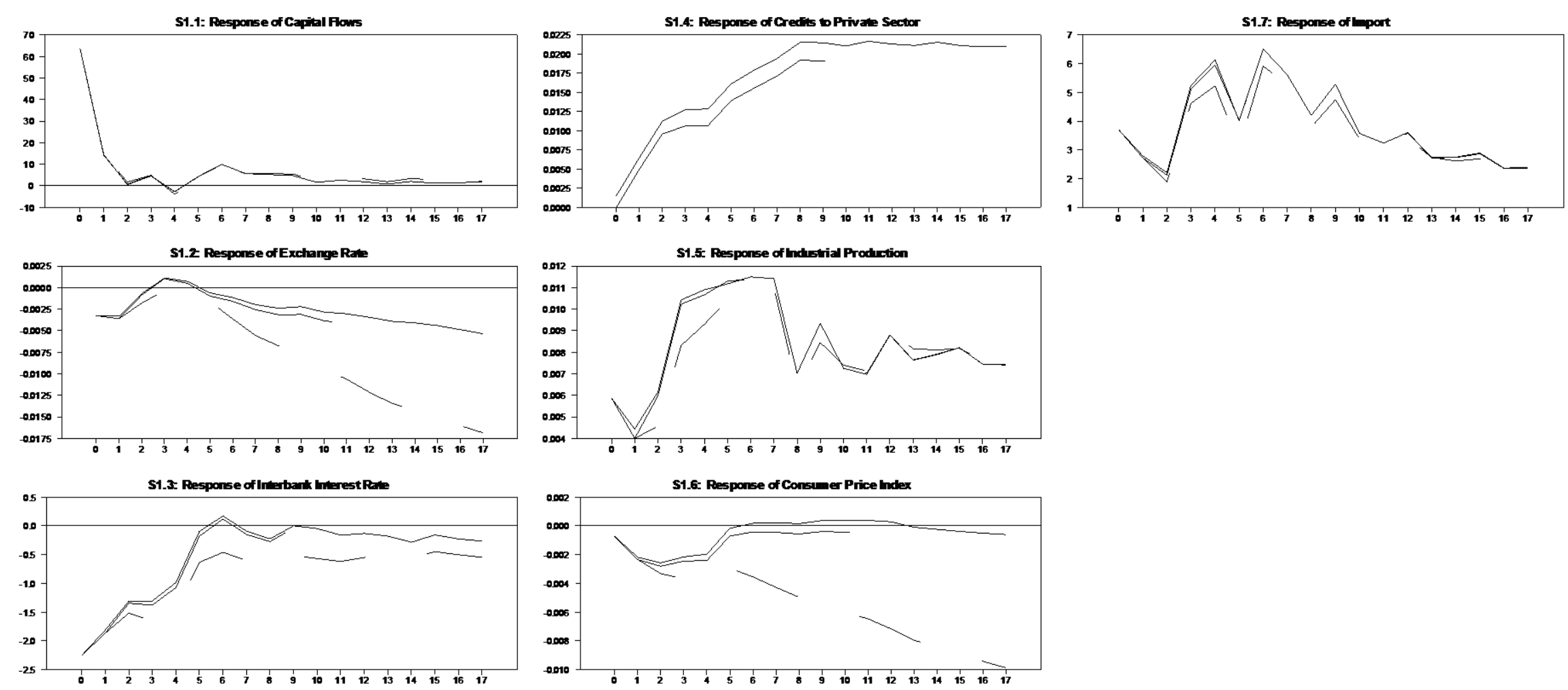

Note: The solid line represents the impulse response of the unconstrained specification. The dotted line represents the impulse response when credit is kept constant. The dashed line represents the impulse response for when credit does not change with capital flows but changes with other variables. 
The following is the base model, where Export-Import ratio in absolute value is used as the additional variable.

\section{S2: Responses to Credits with Import/Export}
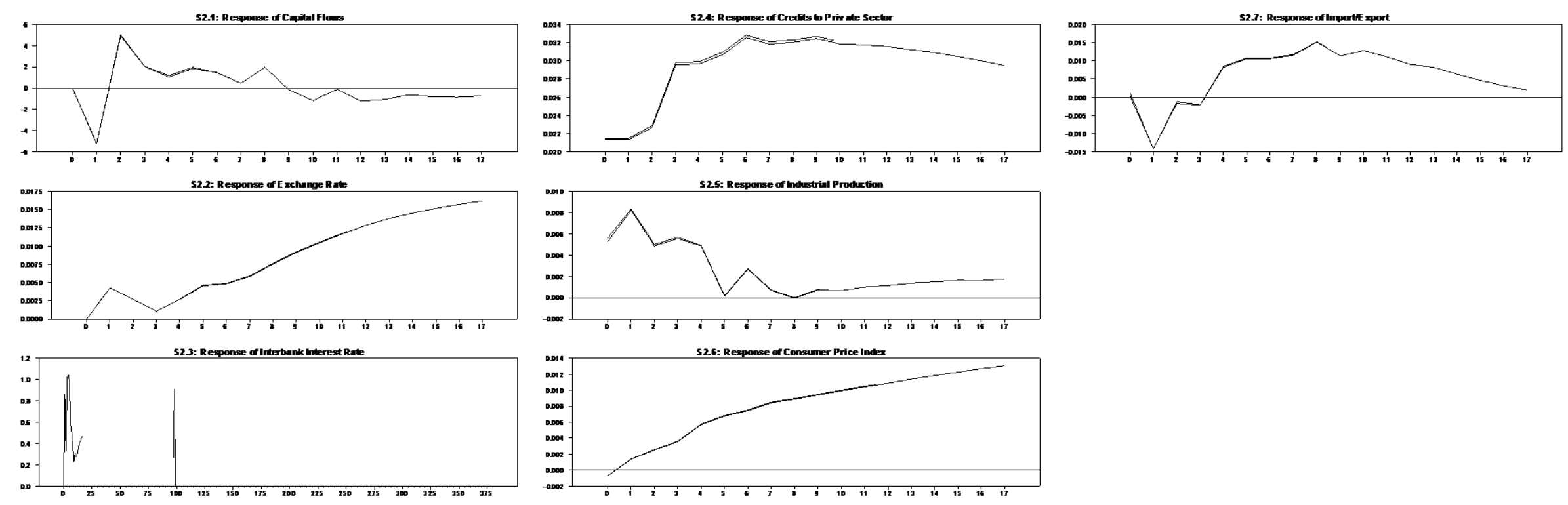

Note: The solid line represents the impulse response of the unconstrained specification. The dashed line represents the impulse response for when credit does not change with capital flows but changes with other variables. 